\title{
IMMUNOMODULATORY B-GLUCANS ENHANCE THE WOUND HEALING ABILITY OF CHLOROFORM FRACTION OF ACHYRANTHES ASPERA L
}

\section{Authors:}

1. Krishnaraju Venkatesan, $\mathrm{PhD}$, King Khalid University, K.S.A

2. Fazil Ahmad, PhD, Imam Abdulrahman Bin Faisal University, K.S.A

3. Rasheed Ahemad Shaik, PhD, King Abdulaziz University, K.S.A

4. Kayamkani Abedulla Khan, PhD, IBN Sina National College for medical studies, K.S.A

5. Doaa Ahmed Ebrahim Radwan, Ph.D, Imam Abdulrahman Bin Faisal University, K.S.A

6. Jamal Moideen Muthu Mohamed, PhD, Shri Indra Ganesan Institute of Medical Science, India

7. Premalatha Paulsamy, PhD, King Khalid University, K.S.A

8. Ester Mary Pappiya, Ph.D, Ministry of Health, Najran, K.S.A

9. Geetha Kandasamy, PhD, King Khalid University, K.S.A

10. Rajalakshimi Vasudevan, PhD, King Khalid University, K.S.A

11. Kumarappan Chidambaram, Ph.D, King Khalid University, K.S.A

12. Kumar Venkatesan, PhD, King Khalid University, K.S.A

13. Kalaiselvi Periannan, $\mathrm{PhD}$, Oxford Brookes University, UK

14. Kalpana Krishnaraju, Erode College of Pharmacy, Erode, India

\section{Department(s) and institution(s):}

${ }^{* 1}$ Krishnaraju Venkatesan, Department of Pharmacology, College of Pharmacy, King Khalid University, Abha, Asir Province, Saudi Arabia. Email: kvenkatesan@kku.edu.sa. Mobile: +966-504839653. ORCID ID: 0000-0003-2853-5907

${ }^{2}$ Fazil Ahmad, Department of Anesthesia Technology, College of Applied Medical Sciences in Jubail, Imam Abdulrahman Bin Faisal University, P.O. Box 4030, Jubail, Saudi Arabia. Email: fmahmad@iau.edu.sa, https://orcid.org/0000-0002-0483-4702

${ }^{3}$ Rasheed Ahemad Shaik, Department of Pharmacology \& Toxicology, Faculty of Pharmacy, King Abdulaziz University, Jeddah, Kingdom of Saudi Arabia. Email: drrasheedshaik@gmail.com, ORCID: https://orcid.org/0000-0001-7959-8647 
${ }^{4}$ Kayamkani Abedulla Khan, Pharmacology and Clinical Pharmacy Department, IBN Sina National College for medical studies, Ghulail, Almahajar, Jeddah, KSA, Email: abidulla.k@gmail.com

${ }^{5}$ Doaa Ahmed Ebrahim Radwan, Ass. Professor in Respiratory Department, College of Applied Medical Sciences in Jubail, Imam Abdulrahman Bin Faisal University, KSA. Email:daradwan@iau.edu.sa

${ }^{6}$ Jamal Moideen Muthu Mohamed, College of Pharmacy, Shri Indra Ganesan Institute of Medical Science, Tiruchirappalli 620012, Tamil Nadu, India. Email: jmuthumohamed@gmail.com, ORCID: https://orcid.org/0000-0001-6362-8629

${ }^{7}$ Premalatha Paulsamy, College of Nursing, Mahalah Branch for Girls King Khalid University, Asir Province, Saudi Arabia., Email: pponnuthai@kku.edu.sa, Mobile: +966-563595142. ORCID ID: 0000-0001-5117-480X

${ }^{8}$ Ester Mary Pappiya, Regional Nursing Administration, Directorate of General Health Affair, Ministry of Health, Najran, Kingdom of Saudi Arabia. Email: easterbala@gmail.com. Mobile: +966-509180584, ORCID ID: 0000-0003-1188-8845

${ }^{9}$ Rajalakshimi Vasudevan, Department of Pharmacology, College of Pharmacy, King Khalid University, Abha, Asir Province, Saudi Arabia. Email: raja@kku.edu.sa, Mobile: +966508426425. ORCID ID: 0000-0002-1173-7724

${ }^{10}$ Geetha Kandasamy, Department of Pharmacology, College of Pharmacy, King Khalid University, Abha, Asir Province, Saudi Arabia. Email: glakshmi@kku.edu.sa, Mobile: +966559208567

${ }^{11}$ Kumarappan Chidambaram, Department of Pharmacology, College of Pharmacy, King Khalid University, Abha, Asir Province, Saudi Arabia. Email: kumarappan@kku.edu.sa. Mobile: +966-509291037. ORCID ID:0000-0002-7981-4562

${ }^{12}$ Kumar Venkatesan, Department of Pharmaceutical Chemistry, College of Pharmacy, King Khalid University, Abha, Asir Province, Saudi Arabia. Email: kumarve@kku.edu.sa. Mobile: +966-505735246. ORCID ID:0000-0001-5077-9380

${ }^{13}$ Kalaiselvi Periannan, Lecturer in Mental health Nursing, Oxford School of Nursing \& Midwifery, Faculty of health and life sciences, Oxford, OX3 0FL, Email: kperiannan@brookes.ac.uk, Mobile: + 07838361434

${ }^{14}$ Kalpana Krishnaraju, Erode College of Pharmacy, Tamil Nadu Dr. M.G.R. Medical University; rnkkalpana@gmail.com

- Corresponding Author 


\begin{abstract}
:
Introduction: Wound healing is a multifaceted biological process, and diabetic wounds add more complexity to it. In diabetic wounds, the combination of chloroform fractions of Achyranthes aspera L. (A.aspera) leaves with $\beta$-Glucans has not been investigated. The additive effect of these two (A.aspera $+\beta$-Glucans) would benefit the inflammatory phase of diabetic wounds, as improper treatment will lead to chronic injuries. Therefore, the goal of this research work was to assess the in-vivo wound healing and anti-inflammatory effects of a combination of chloroform fractions of A.aspera leaves and $\beta$-Glucans in a variety of wound models in STZ-induced diabetic rats.
\end{abstract}

\title{
Methods:
}

Preliminary phytochemical analyses of A.aspera were conducted to identify various phytoconstituents in the test extract. Acute and sub-acute dermal toxicity tests of A.aspera were carried out on mice and rats, respectively, to see whether there were any abnormalities. Excision and incision wound models, cotton pellet-induced granuloma models, rat paw edema and burn wounds were used to test wound healing and anti-inflammatory actions. To induce diabetes, streptozotocin (STZ) was administered intraperitoneally at a dosage of $65 \mathrm{mg} / \mathrm{kg}$ (i.p.). A.aspera $(10 \% \mathrm{w} / \mathrm{w})$ and $\beta$-Glucans $(2 \% \mathrm{w} / \mathrm{w})$ ointments were tested separately and in combination for wound healing activities. Silver sulfadiazine $(1 \% \mathrm{w} / \mathrm{w})$ ointment was used to treat the positive control groups. Excision wound model rats that had been treated with basic ointment were used as negative controls, as were incision wound model rats that had not been treated. A.aspera (400 mg/kg, po) and $\beta$-Glucans (30 mg/kg, po) were tested separately and in combination for anti-inflammatory efficacy. Positive control groups were given indomethacin $(10 \mathrm{mg} / \mathrm{kg}$, po) for cotton pellet-induced granuloma and rat paw oedema models. Negative controls for both anti-inflammatory activity models were provided $2 \%$ Tween 80 . The groups were made up of six rats, and the treatments were given topically and orally to assess wound healing and anti-inflammatory effects. The levels of hydroxyproline and hexosamine and the antioxidant enzymes (SOD and CAT) in the granulation tissue were measured in excision wound model. Healed excision wound skin was examined histopathologically.

Results: The A.aspera and $\beta$-Glucans combination resulted in a significant percentage of wound contraction and a shorter epithelialization time $(\mathrm{P}<0.01)$. The combination was found to be the most effective, with the highest percentage of edema reduction $(55 \% ; \mathrm{p}<0.01)$. The 
combination also exhibited favourable hydroxylamine, hexosamine and anti-oxidant profiles supported by histopathology data.

Conclusion: This research showed that the immunomodulatory effect of $\beta$-Glucans had significantly enhanced the wound healing, anti-inflammatory, and anti-oxidant potential of A.aspera in diabetic wounds.

Keywords: Diabetic wound, Achyranthes aspera, wound healing, burn wound, cotton, pellet granuloma, carrageenan-induced paw edema, Acute toxicity

\section{Introduction:}

The spatial and temporal coordination of the inflammatory phase with tissue regeneration and remodeling makes wound healing one of the most complicated processes in the human body. A diabetic's ability to heal acute wounds is impaired. Hypoxia, neovascularization and impaired angiogenesis, dysfunction in fibroblasts and epidermal cells, damage from reactive oxygen species (ROS) and AGEs (advanced glycation end-products), decreased host immune resistance, high levels of metalloproteases, and neuropathy are features that can lead to impaired healing in diabetics. ${ }^{1}$

Hemostasis, inflammatory period, proliferation, and tissue remodelling are the four phases of wound healing that are closely linked and overlap. ${ }^{2}$ These phases and their physiological activities must occur in the correct order, at a specific moment, and at an ideal intensity for a particular length. If it does not happen in order, it will lead to delayed acute wounds and chronic wounds. Due to a partial, delayed or disorganized healing process, such wounds commonly develop pathologic inflammation. ${ }^{1,3-4}$ As a result, the injured tissue's requirements during all three phases must be satisfied for a wound to heal in the proper order. A multi-modal therapy strategy appears to be a viable alternative for achieving this. We used A.aspera and $\beta$-Glucans to try to do this.

$\beta$-Glucans are carbohydrate polymers present in the cell walls of bacteria, fungi, yeasts, and certain cereals, including barley and oats. ${ }^{5-7}$ Many kinds of $\beta$-glucans have a wide range of anti-inflammatory, anti-inflammatory, and wound-healing properties and significant roles in immunological, anti-inflammatory, and wound-healing responses. They induce defence responses against pathogen infection or injury by activating the immune system. Pattern recognition receptors on target cells, macrophages, primarily monocytes, neutrophils, and 
natural killer cells (as well as skin cells like keratinocytes and fibroblasts), mediate these effects. ${ }^{5,8-9}$

Mammalian $\beta$-glucans are not present or synthesized. When they are presented to a host, they are recognized as 'foreign' by the innate and adaptive immune systems, resulting in an influx of macrophages. Macrophages are essential to wound cleaners that use phagocytosis to clear the wound of devitalized tissue and dead neutrophils. They also express a variety of growth factors, which aid cellular proliferation, angiogenesis, and extracellular matrix deposition, resulting in wound re-epithelialization and increased tensile strength. Macrophage activity has been critical in the inflammatory, proliferative, and remodelling stages of healing. ${ }^{10}$

A.aspera, often known as apamarga, is a profuse and wild plant native to India. Folk healers and locals in Karungal village, Kanyakumari district, Tamil Nadu, India, use the plant's leaves to treat wounds. Wound healing, cancer-fighting, hepatoprotective, immunomodulatory, antibacterial properties have all been discovered in A.aspera. ${ }^{11}$

According to the research findings cited above, $\beta$-glucans show significant immunomodulatory activity $^{5}$, whereas A.aspera has intense anti-inflammatory action. ${ }^{6}$ The combination might be helpful in efficiently meeting the needs of wound tissue in all three phases, and more specifically, in the inflammatory phase. Furthermore, the lack of studies on $\beta$-glucans + A.aspera impact on diabetic wound healing emphasises the relevance and uniqueness of this research.

\section{Materials and Methods:}

\section{Preparation of extracts:}

By employing the Mengie T et al. method, the air-dried and powdered A. aspera leaves were first defatted and then extracted and fractionated. ${ }^{12}$ The plant material was extracted using the cold maceration extraction method. One kilogram of powder was macerated for 72 hours in an $80 \%$ methanol $(1: 6 \mathrm{w} / \mathrm{v})$ containing flask. The extraction was performed two more times to get the maximal extraction. The solvent was evaporated using a rotary evaporator under decreased pressure to produce dried methanolic extract $(115.22 \mathrm{gm})$ of the leaves. In a separating funnel, a portion of the dried methanolic extract was suspended in distilled water and fractionated with choloroform. The extraction process was repeated three times. The 
chloroform fractions were concentrated using a rotary evaporator before drying at $40^{\circ} \mathrm{C}$ in a dry oven. The dried fraction yielded $40.23 \mathrm{~g}$ in terms of percentage yields.

\section{Preliminary phytochemical tests:}

Standard assays were used to screen for secondary metabolites in chloroform fractions of an $80 \%$ extract (methanol) of A. aspera leaf. . ${ }^{12-14}$

Test for Flavonoids:

On a water bath, $10 \mathrm{~mL}$ ethyl acetate was added to $0.2 \mathrm{~g}$ of the chloroform fraction and heated for 3 minutes. After that, filtrate $(4 \mathrm{ml})$ was mixed with weak ammonia solution $(1 \mathrm{ml})$ and shaken. The mixture was filtered and chilled. The layers were permitted to separate, and the yellow color revealed the presence of flavonoids in the ammonia layer.

Test for Terpenoids:

Chloroform $(2 \mathrm{ml})$ was added to $0.25 \mathrm{~g}$ of the fraction. Then, to build a coating, pure sulfuric acid $(3 \mathrm{ml})$ was carefully applied. A reddish-brown colour of the interface suggested the presence of terpenoids.

Test for Saponins:

Distilled water $(5 \mathrm{ml})$ was added to $0.25 \mathrm{~g}$ of the fraction. The solution was then forcefully agitated, and a stable, continuous foam was seen. Saponins were detected by the development of a steady froth present for about half an hour.

Test for Tannins:

In a test tube, choloform fraction $(0.25 \mathrm{~g})$ was heated in $10 \mathrm{~mL}$ of water. It is then filtered through Whatman filter paper (No.1). To the filtrate, a few drops of ferric chloride ( $0.1 \%)$ were added. A brownish-green or blueblack precipitate indicated the presence of tannins.

Test for Steroids:

With $2 \mathrm{~mL}$ sulfuric acid, acetic anhydride $(2 \mathrm{ml})$ was added to $0.25 \mathrm{~g}$ of each fraction. Change in color to blue or green from violet indicates the presence of steroids. 
Test for Cardiac Glycosides:

Glacial acetic acid $(2 \mathrm{ml})$ and ferric chloride solution (one drop) were added to the diluted fraction $(0.25 \mathrm{~g}$ with $5 \mathrm{~mL}$ water). $1 \mathrm{~mL}$ of concentrated sulfuric acid was used as a base. Brown ring at the interface shows the presence of a deoxysugar (cardenolides).

Test for Alkaloids:

The choloform fraction $(0.5 \mathrm{~g})$ was added with a few drops of freshly produced Mayer's reagent. The production of cream determined the presence of alkaloids.

\section{Ointment processing}

According to Suntar et al., a simple ointment base will be made using a 3:6:1 ratio of glycol stearate, propyleneglycol, and liquid paraffin. ${ }^{15}$ Appropriate amounts of test will be added to the simple ointment basis for test ointments [ $2 \% \mathrm{w} / \mathrm{w} \beta$-Glucans (beta-D Glucan produced from Saccharomyces cerevisiae, Meteoric Biopharmaceuticals Private Limited, India), $10 \%$ (w/w) A.aspera, and $2 \% \mathrm{w} / \mathrm{w} \beta$-glucans $+10 \% \mathrm{w} / \mathrm{w}$ A.aspera The vehicle group will be treated topically with just the ointment base. As a reference medication, $1 \%$ silver sulphadiazine ointment (Positive control) will be utilized. $0.5 \mathrm{~g}$ of the ointments or reference medication will be applied topically to the wound sites once daily during the treatment period, depending on group assignment.

\section{Experimental animals and housing conditions:}

Acute toxicity tests were conducted using male and female Swiss albino mice (20-25 g). Subacute dermal toxicity and wound healing capacity was assessed using Wistar albino rats of both sexes weighing 150-250 g, respectively. The animals were housed in cages made of polypropylene with optimum light, humidity, temperature (Temp: $25 \pm 2{ }^{\circ} \mathrm{C}$, light/dark cycles $(12 / 12 \mathrm{~h})$, and $75 \%$ relative humidity). Animals were fed with a commercial pellet rat diet and water ad libitum in the laboratory animal room for at least one week before testing. The Institutional Animal Ethics Committee (IAEC) of King Khalid University in Abha, Saudi Arabia (ECM\#2021-5304, Dated 02.05.21) approved all experimental procedures. Experiments were carried out as per the guidelines for laboratory animal care and use. 


\section{0: Acute toxicity test}

Non-pregnant and nulliparous female albino mice aged 8-10 weeks and weighing $28 \pm 4 \mathrm{~g}$ were selected randomly following OECD Test Guidelines 425 (Up and Down Procedure). ${ }^{16 .}$ For five days, the animals were housed in normal circumstances. The limit test was done with a single dose of $2000 \mathrm{mg} / \mathrm{kg}$ p.o. Before dosing, the mice were fasted for 3-4 hours but had access to free water. Based on the bodyweight of the animal, the defined dosage was given to single female mice. The animals were attentively monitored for the first 30 minutes and then for the next 4 hours. After 1-2 hours after medication, food was given. Following the survival of the treated mice, four more mice were given the same dose maintaining the same set-up. For the control group (vehicle-treated), the same technique was used for a group of 5 mice that were given $1 \%$ Carboxymethylcellulose (CMC) gel in the same volume as the treated mice. Within the first 6 hours, both groups were thoroughly monitored for any harmful effects and subsequently at regular intervals (every 24 hours) for a total of 14 days. General signs and toxicity symptoms were observed in the animals, including somatomotor activity and behavioral pattern, mucous membranes and eyes, changes in skin and fur, salivation and diarrhea, tremor and convulsions, weight loss, food and water intake, paralysis and lethargy, and mortality. ${ }^{16}$

\section{Sub-acute dermal toxicity:}

The test was carried out by the OECD guideline 410 for chemical testing. ${ }^{17}$ For two weeks, healthy adult young male rats of 6-8 weeks were housed in the laboratory conditions. Rats were randomly allocated to control and treatment groups. For all the test animals, fur was removed from the trunk part on the dorsal region shortly before testing (24 hours). Shaving was done at about weekly intervals. For the application of the test material, a body surface area of approximately $10 \%$ was removed. There are six healthy male rats in each group $(n=6)$. The test substance $(2000 \mathrm{mg} / \mathrm{kg} / \mathrm{d})$ is administered to the skin of experimental animals once a day with a gauze patch for a total of 28 days. A semiocclusive bandage was used to keep the patch in place for 4 hours, following which it was removed, and the skin was cleansed of any remaining test material. As a control, the ointment base was utilized. The animals were observed daily for changes in their fur, mortality, mucous membranes, eyes, breathing and behavioural (tremors, salivation, convulsions, diarrhoea, and lethargy) patterns during the treatment period. Every week, the rat's body weight was monitored. 


\section{Induction of diabetes:}

Animals were starved overnight. Nicotinamide (HiMedia Labs Pvt. Ltd.), $110 \mathrm{mg} / \mathrm{kg}$ body weight, was adminstered 15 minutes before administering streptozotocin (STZ). A freshly generated STZ (Sigma, St. Louis, MO, USA) solution dissolved in a citrate buffer of pH 4.5 was administered intraperitoneally (i.p) at a $65 \mathrm{mg} / \mathrm{kg}$ dose. To avoid hypoglycemia produced by high pancreatic insulin production, a $10 \%$ glucose solution was given to rats for an extra 24 hours after STZ therapy. Blood was collected from the rats' tail veins 72 hours after they were injected with STZ. Rats having a blood glucose level (fasting) $>200 \mathrm{mg} / \mathrm{dl}$ were declared diabetic and utilized in this study. ${ }^{18}$

\section{Wound healing activity}

\section{Excision wound model:}

The animals were split into five groups of six rats for the excision wound model, with the first group receiving simple ointment. Nitrofurazone $0.2 \%$ ointment for the second group. The third group with $\beta$-Glucans and the fourth group with $10 \%$ ointments made from chloroform fractions of A. aspera leaves. The fifth group was given $\beta$-Glucans + A. aspera.

ketamine (I.p. $50 \mathrm{mg} / \mathrm{kg}$ ) was used to anesthetize rats. ${ }^{19}$ Removal of fur from the dorso-thoracic area was done. On day 0, for removal of a full-thickness skin, a circular mark of $314 \mathrm{~mm} 2$ was made with a permanent marker, and the skin was removed with sharp, sterilized scissors, as reported by Nagar. ${ }^{20}$ Ointments were administered as stated above from day one, i.e. after 24 hours after establishing a wound area. All ointments were administered to the wound area once a day until they healed fully. Every two days, the wound closure of the rats was monitored, and the measurements were collected using clear paper and with the help of a permanent marker. Utilising a millimetre scaled ruler, the diameter of the wound was measured. The following formula $^{12}$ assessed the percentage of wound contraction

$\%$ Wound contraction $=[($ Day zero wound area - Particular day wound area $/$ Day zero wound area) $] \times 100$

The total days it took for the tissue that is dead to slip off the surface of the wound without leaving a raw wound was regarded as the complete epithelialization endpoint. The days it took for this endpoint were termed an epithelialization period. ${ }^{12}$ 


\section{Incision wound model:}

Animals are grouped and dosed as indicated in the above excision wound model. Fur was removed after sedating the rats in the same way as the excision wound method described above. A linear-paravertebral incision of $3 \mathrm{~cm}$ was performed one $\mathrm{cm}$ from the midline on either side of the vertebral column through the whole thickness of the skin. The excised skin was brought together and stitched at $1-\mathrm{cm}$ intervals with chromic catgut (dimension: 2/0 metric-1/ 2 circular) utilizing a curved needle on day 0 . The ointments were administered as indicated in Animal Grouping and Dosing from day one. For nine days, the ointments were administered topically once a day. On the eight-day, the sutures were carefully removed. ${ }^{21}$ The tensile strength was then tested on the ninth day using the continuous constant water flow approach to assess the amount of healing. ${ }^{22-23}$

Percentage tensile strength of treatment groups

$=($ Tensile Strenth of treatment arm- Tensile Strength of simple ointment $) /$ Tensile Strength of simple ointment x 100

Percentage tensile strength of reference

$=[($ Tensile Strength of reference- Tensile Strength of simple ointment $) /$ Tensile Strength of simple ointment] x $100^{24}$

\section{Thermal burn wound model:}

Animals are grouped and dosed as indicated in the above excision wound model. On the dorsal skin, the hairs were manually removed 24 hours before the burn was induced. The animals were observed for 24 hours to see if shaving had produced any irritation. A metal rod of 2.5 $\mathrm{cm}$ diameter was heated to $80-85^{\circ} \mathrm{C}$ and pressed for 20 seconds to create thermal burn injuries on the rat's dorsal skin. The wound was then dressed with a clean, sterile gauge, and the animals were kept individually when they had recovered from anaesthetic. The burn was treated with drugs twice a day. The wound closure rate was recorded using transparent paper and a permanent marker on the 5 th, 10 th, and 15 th post-wounding days. ${ }^{25}$ For the final analysis of the data, the percentage of wound closure was determined using the formula below. ${ }^{26-27}$

$\%$ Wound closure $=[($ Day 0 wound area - Day “n” wound area $) /$ Day 0 wound area $]$ x 100 Where $\mathrm{n}=5^{\text {th }}$ day, $10^{\text {th }}$ day, and 15 th post wounding days 


\section{Evaluation of Anti-Inflammatory Activity:}

\section{Carrageenan-Induced Paw Edema:}

The impact of chloroform extract of A. aspera leaf on acute inflammation was studied using Ayal's ${ }^{28}$ technique with slight modifications. The rats were fasted overnight and had unlimited water access until the experiment began. Before administering the drug, the basal volume, or the amount of water displaced by each rat's left hind paw, was noted using a calibrated plethysmometer. The rats were randomly allocated to their separate groups as follows. The control group (first) was treated with $2 \%$ Tween $80,10 \mathrm{~mL} / \mathrm{kg}$. The positive control group (second) was treated with $10 \mathrm{mg} / \mathrm{kg}$ Indomethacin. The third and fourth groups were treated with $\beta$-Glucans (30 mg/kg) and A. aspera (400 mg/kg), respectively. The last group was treated with $\beta$-Glucans $(30 \mathrm{mg} / \mathrm{kg})+\mathrm{A}$. aspera $(400 \mathrm{mg} / \mathrm{kg})$.

Following that, the rats were given test chemicals by oral gavage. After 1 hour after test administration, inflammation was induced in the hind paw (left) by injecting $0.05 \mathrm{~mL}$ of newly made $1 \%$ carrageenan suspension diluted in normal saline into the left hind paw's sub-plantar surface. After $1 \mathrm{hr}, 2 \mathrm{hr}, 3 \mathrm{hr}$, and 4 hours of carrageenan induction, the volume of the injected paw was measured using a plethysmometer. ${ }^{14,12}$

Percentage edema inhibition $=\{($ Paw edema of negative control - Paw edema of test groups $)$ /Paw edema of negative control \} X 100

\section{Cotton Pellet-Induced Granuloma:}

The components of chronic inflammation (transudative and proliferative) were assessed using the approach previously employed by Afsar et al. ${ }^{29}$ Male albino Wistar rats (200-250 g) were housed for overnight fasting and given unrestricted water access until the experiment began. The animals are divided into groups and dosed according to the paw edema method. In an autoclave, sterilization of cotton pellets, each weighing $10 \pm 1 \mathrm{mg}$, for 30 minutes at $120^{\circ} \mathrm{C}$ at $15 \mathrm{Ib}$ pressure. Sedation of the rats with ketamine hydrochloride $(50 \mathrm{mg} / \mathrm{kg}$, i.p. $)$ was done 20 minutes after treatment as per groupings. The subcutaneous tunnel was made aseptically in both sides of each rat's previously shaved groin area with blunted forceps. The subcutaneous tube was then implanted and stitched using chromic catgut (dimension;2/0 metric-1/2 circle) following bilateral insertion of two sterilized cotton pellets measuring $10 \pm 1 \mathrm{mg}$ each. For seven days, rats were orally (once a day) treated with $2 \%$ Tween 80 , indomethacin, and treatment groups. 
On day 8 , the rats were anesthetized, and the pellets enclosed by granuloma tissue were carefully cut out and cleaned of extraneous tissue. After removal, the pellet was weighed immediately, then dried at $60^{\circ} \mathrm{C}$ for 24 hours to a constant weight. After removing the weight of the cotton pellets, the dry weight was calculated.

The procedure below was used to estimate the amount of exudate (mg), amount of granulation tissue created (mg), percent inhibition of exudate, and amount of granuloma tissue formed. ${ }^{12,30}$ Exudate formation $=$ Wet weight of pellet - Dry weight of the pellet.

Granuloma tissue formation $=$ Dry weight of the pellet - Cotton pellet initial weight.

Exudate inhibition $(\%)=\{($ control group exudate - treated group exudate $) /$ control group exudate $\mathrm{X} 100$

\section{Biochemical analyses:}

The rats from the excision were decapitated at the end of the experiment to assess the healing course in terms of biochemical features. The wound area of experimental rats was excised to assess tissue hydroxyproline, hexosamine, malondialdehyde (MDA), glutathione (GSH), catalase (CAT), and superoxide dismutase levels (SOD).

\section{Estimation of hydroxyproline and hexosamine}

The concentration of hydroxyproline, the most frequent indication of collagen turnover, was measured in granulation tissue from the healed wound area of an excision wound. Tissues were dried in a hot air oven at $60-70^{\circ} \mathrm{C}$ to a consistent weight, then hydrolyzed in $6 \mathrm{~N} \mathrm{HCl}$ at $130^{\circ} \mathrm{C}$ for 4 hours in a sealed tube. After neutralization to $\mathrm{pH} 7.0$, the hydrolysate was subjected to chloramine-T oxidation for 20 minutes before being halted by adding $0.4 \mathrm{M}$ perchloric acid. The color was made using Ehrlich reagent at $60^{\circ} \mathrm{C}$ and detected with a UV-Vis spectrophotometer at $557 \mathrm{~nm}$ (Shimadzu, Columbia, MD). ${ }^{31}$

For hexosamine determination, the weighted granulation tissues were hydrolyzed for 8 hours at $98^{\circ} \mathrm{C}$ in $6 \mathrm{~N} \mathrm{HCl}$, neutralized to $\mathrm{pH} 7$ with $4 \mathrm{~N} \mathrm{NaOH}$, and diluted with distilled water. The diluted solution was heated to $96^{\circ} \mathrm{C}$ for 40 minutes after being combined with acetyl acetone solution. After cooling the mixture, ethanol (96\%) was added, and then a solution of pdimethylaminobenzaldehyde (Ehrlich's reagent) was added. After the solution had been well mixed and allowed to cool for 1 hour, at $530 \mathrm{~nm}$, the absorbance was measured using a Shimadzu double beam UV-Vis spectrophotometer. A standard curve was used to determine 
the quantity of hexosamine. The content of hexosamine was measured in milligrams per gram of dry tissue weight. ${ }^{31}$

\section{Estimation of antioxidant activity}

To assess antioxidant activity, blood was drawn from the retro-orbital plexus of cotton-pellet animal models on days 1 and 8 and centrifuged for 10 minutes at $506.11 \mathrm{~g}$ (Micro centrifuge) to separate plasma. The antioxidative enzyme test was performed using the serum. The amount of thiobarbituric acid reactive substances (TBARS) was measured using the Uchiyama and Mihara technique to evaluate the degree of lipid peroxidation (LPO). The levels of reduced glutathione (GSH) were determined using the Sedlak and Lindsay technique, while the activities of superoxide dismutase (SOD) were determined using the Kono method. Catalase (CAT) was measured using Aebi's standard technique. ${ }^{31}$

\section{Estimation of proinflammatory and anti-inflammatory cytokine induction:}

On days 1 and 8 after wounding, blood samples were taken from dead space wound animals in each group. The levels of proinflammatory (TNF and IL-6) and anti-inflammatory (IL-10) cytokines were determined using commercially available enzyme-linked immunosorbent assays (ELISAs). The assays were carried out as directed by the manufacturer. By plotting the graph for the standard, the cytokine concentrations were calculated in pg/ml. To confirm the correctness of the results, each experiment was repeated three times. ${ }^{32}$

\section{Histopathologic study:}

At the end of the experiment, the histological changes of the excised wound tissue (healed) were investigated by cutting cross-sectional wound tissues of full-thickness from all groups. The skin tissues will be embedded in paraffin wax after being treated with formaldehyde (10\%). Sections will be cut to a thickness of around $5 \mathrm{~mm}$, deparaffinized, and the staining was done with hematoxylin and eosin (H\&E). Histological alterations such as neovascularization (angiogenesis), fibroblast proliferation, inflammatory cell infiltration, and epidermal remodelling were observed under a light microscope of $100 \mathrm{x}$ magnification. The findings of the various animal groups were examined blindly and compared to those of the control group. ${ }^{33}$

\section{Statistical analysis:}

Dunnett's test was used to examine differences between means after data were submitted to analysis of variance (ANOVA). At a $\mathrm{P}<0.01$ threshold of significance, a substantial difference 
was considered. The mean and standard error of the mean (SEM) of six animals are represented $(n-6)$.

\section{Result:}

According to phytochemical screening, alkaloids, terpenoids, Tannins, Flavonoids, Cardiac Glycosides, and Steroids were found in the chloroform fraction of the A.aspera extracts (Table1).

Table 1: Chloroform Fractions of A. aspera Leaf Extract: A Preliminary Screening of

\begin{tabular}{|l|l|}
\hline Phytochemical constituents & Chloroform fraction \\
\hline Saponins & Absent \\
\hline Terpenoids & Present \\
\hline Tannins & Present \\
\hline Flavonoids & Present \\
\hline Cardiac Glycosides & Present \\
\hline Steroids & Present \\
\hline Alkaloids & Present \\
\hline
\end{tabular}

\section{Acute oral and sub-acute dermal toxicity tests:}

Acute oral toxicity and 14 days subacute dermal toxicity experiments on chloroform fractions of $80 \%$ A. aspera methanol leaf extract revealed no gross behavioral changes, toxic skin effects, or mortality within 24 hours or during the next 14 days, respectively. The oral LD50 of solvent fractions in rats was more than $2000 \mathrm{mg} / \mathrm{kg}$, according to OECD guideline 425 "Limit Test".

\section{Excision wound model:}

In the excision wounds, rats treated with A.aspera and A.aspera $+\beta$-Glucans combination ointments showed enhanced healing of wounds. The proportion of wound contraction in the A.aspera $+\beta$-Glucans ointment rats was higher and significant $(\mathrm{P}<0.01)$ than the negative control in most post-wounding days, and the time of epithelialization was shortened (Table 2)., The contraction of wounds in the A.aspera $+\beta$-Glucans ointment treated group was greater or equivalent in most post-wounding days than that of the positive control (SS 1\% w/w). On days 
8, 16 and 18, it was 67.70 and $57.41 \%$; 98.65 and $98.05 \%$; and 99.66 and $99.53 \%$ on for A.aspera $+\beta$-Glucans ointment and SS $1 \%$ ointments, respectively. The contractions of wounds in the rats treated with $\beta$-Glucans and SS $1 \% \mathrm{w} / \mathrm{w}$ ointments, on the other hand, were significantly different. As a result, the most active group is A.aspera $+\beta$-Glucans ointment, as indicated by a more significant percentage of contractions of the wound and a shorter epithelialization duration (Table 2)

Table -2: Effect of A.aspera and $\beta$-Glucans alone and in combination on excision wounds

\begin{tabular}{|c|c|c|c|c|c|c|}
\hline & Excisic & wound area & $\mathrm{nm}^{2}$ ) and $\%$ & ontraction & & \\
\hline $\begin{array}{l}\text { Treatment } \\
\text { Groups }\end{array}$ & Day 2 & Day 8 & Day 14 & Day 16 & Day 18 & $\begin{array}{l}\text { Epithelization } \\
\text { time (d) }\end{array}$ \\
\hline Control & $\begin{array}{l}310.00 \\
\pm \quad 2.3 \\
(1.6)\end{array}$ & $\begin{array}{l}222.46 \pm 3.59 \\
(29.40)\end{array}$ & $\begin{array}{l}96.70 \pm 6.31 \\
(69.31)\end{array}$ & $\begin{array}{l}61.60 \pm 3.0 \\
(80.45)\end{array}$ & $\begin{array}{l}40.24 \pm 4.02 \\
(87.23)\end{array}$ & $19.33 \pm 0.21$ \\
\hline $\begin{array}{l}\text { Silver } \\
\text { sulfadiazine } \\
(1 \% \mathrm{w} / \mathrm{w})\end{array}$ & $\begin{array}{l}295.32 \\
\pm \quad 2.6 \\
(6.31)\end{array}$ & $\begin{array}{l}134.34 \pm 6.63 \\
(57.41)\end{array}$ & $\begin{array}{l}31.29 \pm 2.10^{*} \\
(90.07)\end{array}$ & $\begin{array}{l}6.14 \pm 0.83 \\
(98.05)\end{array}$ & $\begin{array}{l}1.46 \pm 0.41 * \\
(99.53)\end{array}$ & $14.17 \pm 0.31 *$ \\
\hline$\beta$-Glucans & $\begin{array}{l}302.14 \\
\pm \quad 2.4 \\
(4.14)\end{array}$ & $\begin{array}{l}155.12 \pm 5.6 \\
(50.80)\end{array}$ & $\begin{array}{ll}64.25 \pm & 3.5 \\
(79.62) & \end{array}$ & $\begin{array}{l}43.14 \pm 1.52 \\
(86.31)^{*}\end{array}$ & $\begin{array}{l}22.46 \pm \\
0.54 * \\
(92.87)\end{array}$ & $16.01 \pm 0.14 *$ \\
\hline A.aspera & $\begin{array}{l}299.23 \\
\pm \quad 2.6 \\
(5.07)\end{array}$ & $\begin{array}{l}134.12 \pm 5.10 * \\
(57.45)\end{array}$ & $\begin{array}{l}54.24 \pm 2.94 \\
(82.79)\end{array}$ & $\begin{array}{l}28.25 \pm 1.64 * \\
(91.03)\end{array}$ & $\begin{array}{l}14.76 \pm 0.61 * \\
(95.31)\end{array}$ & $14.83 \pm 0.21 *$ \\
\hline $\begin{array}{l}\text { A.aspera + } \\
\beta \text {-Glucans }\end{array}$ & $\begin{array}{l}295.43 \\
\pm 2.45 \\
(6.30)\end{array}$ & $\begin{array}{l}101.84 \pm 4.36^{*} \\
(67.70)\end{array}$ & $\begin{array}{l}22.21 \pm 1.8 * \\
(92.96)\end{array}$ & $\begin{array}{l}4.16 \pm 0.92 * \\
(98.68)\end{array}$ & $\begin{array}{l}1.06 \pm 0.23 * \\
(99.66)\end{array}$ & $13.65 \pm 0.26 *$ \\
\hline
\end{tabular}

The results are shown as mean \pm S.E.M of six rats $(n=6) . * P<0.01$ is the statistical difference from control

\section{Incision wound model:}

When compared to control groups (simple ointment treated), groups treated with A.aspera + $\beta$-Glucans ointment exhibited a substantial $(\mathrm{P}<0.01)$ enhancement in tensile strength in the incision wound model. When SS $1 \%$ ointment and A.aspera $+\beta$-Glucans ointments were compared to A.aspera and $\beta$-Glucans alone treated ointments, tensile strength was considerably enhanced $(\mathrm{P}<0.01)$ (Table 3). 
Table 3: Tensile Strength in Rats: Effect of A.aspera and $\beta$-Glucans alone and in combination

\begin{tabular}{|l|l|l|}
\hline Treatment arm & Tensile Strength $(\mathbf{g})$ & Tensile Strength $(\%)$ \\
\hline Control & $475.82 \pm 72.21$ & - \\
\hline Silver sulfadiazine $(1 \%$ w/w) & $876.15 \pm 42.32^{*}$ & 84.13 \\
\hline$\beta$-Glucans & $851.36 \pm 44.35^{*}$ & 78.92 \\
\hline A.aspera & $872.25 \pm 32.32^{*}$ & 83.31 \\
\hline A.aspera $+\beta$-Glucans & $891.22 \pm 24.43^{*}$ & 87.30 \\
\hline
\end{tabular}

The results are shown as mean \pm S.E.M of six rats $(n=6) .{ }^{*} \mathrm{P}<0.01$ is the statistical difference from control

\section{Carrageenan-Induced Paw Edema:}

The injection of $1 \%$ carrageenan resulted in a gradual increase in paw thickness that peaked 2 hours after administration of $2 \%$ Tween 80 (Table 4). When compared to $2 \%$ Tween 80 , A.aspera $+\beta$-Glucans exhibited a substantial reduction of paw oedema commencing at $1 \mathrm{hr}$ and lasting until 4 hrs $(\mathrm{P}<0.01)$. The anti-inflammatory effect was at its peak four hours after induction in Indomethacin, $+\beta$-Glucans, A.aspera, and A.aspera $+\beta$-Glucans, with respective values of $52.5 \%, 25 \%, 50 \%$, and $55 \%(\mathrm{R} 2=0.90)$.

Significant changes were also seen when comparing A.aspera $+\beta$-Glucans to other treatments. For example, at 1, 2, 3, and 4 hours, A.aspera $+\beta$-Glucans had a substantially different impact than A.aspera extract $(\mathrm{P}<0.01)$. A.aspera alone showed a statistically significant decrease in paw edema compared to $2 \%$ Tween 80 at $1,2,3$, and 4 hours after induction $(\mathrm{P}<0.01)$. $\beta$-Glucans, on the other hand, did not demonstrate any substantial reduction of paw edema as compared to $2 \%$ Tween 80 during the course of the study.

When compared to $2 \%$ Tween 80 , Indomethacin $(10 \mathrm{mg} / \mathrm{kg})$ significantly $(\mathrm{P}<0.01)$ decreased paw edema from the first to the fourth hour following injection of carrageenan. Furthermore, there was no change in the start and duration of action between Indomethacin, $\beta$-Glucans, A.aspera, and A.aspera $+\beta$-Glucans, all exhibited substantial $(\mathrm{P}<0.01)$ reduction of paw edema up to fourth hours after induction. Nonetheless, A.aspera alone showed a similar antiinflammatory effect with indomethacin $(10 \mathrm{mg} / \mathrm{kg})$ throughout the study. The most active 
therapy was A.aspera $+\beta$-Glucans, as shown by the greater proportion of edema inhibition (\%) values of all treatments during the study (Table 4).

Compared to $2 \%$ Tween 80, A.aspera $+\beta$-Glucans and A.aspera substantially reduced the development of granuloma mass and inflammatory exudate $(\mathrm{P}<0.01)$. In both exudate and granuloma inhibition, A.aspera $+\beta$-Glucans showed statistically significant anti-inflammatory efficacy compared to A.aspera $(\mathrm{P}<0.01)$. Compared to the other treatment groups, A.aspera + $\beta$-Glucans showed the greatest percentage reduction of exudate and granuloma development (42.35 and $53.33 \%$, respectively). In Indomethacin, $\beta$-Glucans, A.aspera, and A.aspera $+\beta$ Glucans, there was a statistically significant difference $(\mathrm{P}<0.01)$ in inhibition against exudate $(\mathrm{R} 2=0.822)$ and granuloma development $(\mathrm{R} 2=0.954)$ The A.aspera inhibited exudate production and granulation in a similar way to the standard drug. However, as shown by the higher proportion of inhibition, the A.aspera $+\beta$-Glucans therapy group was the most effective in slowing down the growth of exudate and granuloma mass (Table 5).

Table 4: Paw Edema induced by Carrageenan in Rats: Anti-Inflammatory Effects of A.aspera and $\beta$-Glucans Alone and in Combination

\begin{tabular}{|c|c|c|c|c|c|}
\hline \multirow[t]{2}{*}{ Treatment arm } & \multirow{2}{*}{$\begin{array}{l}\text { Volume at } \\
\text { the Base } \\
(\mathrm{mL})\end{array}$} & \multicolumn{4}{|c|}{$\begin{array}{l}\text { Paw Volume Variation (Mean } \pm \text { SEM) }(\mathrm{mL}) \text { [Percentage } \\
\text { Inhibition }(\%)]\end{array}$} \\
\hline & & $1 \mathrm{Hr}$ & $2 \mathrm{Hrs}$ & 3 Hrs & 4 Hrs \\
\hline $\begin{array}{l}\text { Tween } 80(2 \%) \text {, } \\
10 \mathrm{~mL} / \mathrm{kg}\end{array}$ & $0.21 \pm 0.02$ & $0.44 \pm 01$ & $0.46 \pm 0.01$ & $0.41 \pm 0.02$ & 0.40 \\
\hline $\begin{array}{l}\text { Indomethacin- } \\
10 \mathrm{mg} / \mathrm{kg}\end{array}$ & $0.23 \pm 0.14$ & $\begin{array}{l}0.30 \pm 0.02 \\
(31.81)^{*}\end{array}$ & $\begin{array}{l}0.27 \pm 0.21 \\
(41.30) *\end{array}$ & $\begin{array}{l}0.23 \pm 0.02 \\
(43.90)^{*}\end{array}$ & $\begin{array}{l}0.19 \pm 0.02 \\
(52.5)^{*}\end{array}$ \\
\hline$\beta$-Glucans & $0.21 \pm 0.01$ & $\begin{array}{l}0.39 \pm 01 \\
(11.36)\end{array}$ & $\begin{array}{l}0.35 \pm 0.01 \\
(23.91)\end{array}$ & $\begin{array}{l}0.33 \quad \pm \quad 0.01 \\
(19.51)\end{array}$ & $\begin{array}{l}0.30 \pm 0.01 \\
(25.00)\end{array}$ \\
\hline $\begin{array}{l}\text { A.aspera } 400 \\
\mathrm{mg} / \mathrm{kg}\end{array}$ & $0.21 \pm 0.02$ & $\begin{array}{l}0.31 \pm 0.02 \\
(29.54) *\end{array}$ & $\begin{array}{l}0.29 \pm 0.02 \\
(36.95)^{*}\end{array}$ & $\begin{array}{l}0.23 \pm 0.01 \\
(43.90)^{*}\end{array}$ & $\begin{array}{l}0.20 \pm 0.090 \\
(50.00)^{*}\end{array}$ \\
\hline $\begin{array}{l}\text { A.aspera } 400 \text { } \\
\mathrm{mg} / \mathrm{kg}+\quad \beta- \\
\text { Glucans } 30 \mathrm{mg} / \mathrm{kg}\end{array}$ & $0.21 \pm 0.01$ & $\begin{array}{l}0.28 \pm 0.02 \\
(36.36) *\end{array}$ & $\begin{array}{l}0.26 \pm 0.02 \\
(43.47)^{*}\end{array}$ & $\begin{array}{l}0.22 \pm 0.01 \\
(46.34)^{*}\end{array}$ & $\begin{array}{l}0.18 \pm 0.09 \\
(55.00)^{*}\end{array}$ \\
\hline
\end{tabular}

The results are shown as mean \pm S.E.M of six rats $(n=6) .{ }^{*} \mathrm{P}<0.01$ is the statistical difference from control 


\section{Granuloma Induced by Cotton Pellets :}

Table 5: Effect of A.aspera and $\beta$-Glucans alone and in combination on Rats with Cotton Pellet-Induced Granuloma

\begin{tabular}{|c|c|c|c|c|}
\hline Treatment arm & $\begin{array}{l}\text { Exudates } \\
\text { Mean Weight } \\
\text { in mg (Mean } \pm \\
\text { SEM) }\end{array}$ & $\begin{array}{l}\text { Exudation } \\
\text { Inhibition } \\
\text { Percentage }\end{array}$ & $\begin{array}{l}\text { Granuloma } \\
\text { Mean Weight } \\
\text { in }(\mathrm{mg}) \text { (Mean } \\
\pm \mathrm{SEM})\end{array}$ & $\begin{array}{l}\text { Granulation } \\
\text { Inhibition in \% }\end{array}$ \\
\hline $\begin{array}{l}2 \% \text { Tween } \\
80,10 \mathrm{~mL} / \mathrm{kg}\end{array}$ & $125.32 \pm 0.52$ & - & $143.40 \pm 0.75$ & - \\
\hline $\begin{array}{l}\text { Indomethacin } \\
10 \mathrm{mg} / \mathrm{kg}\end{array}$ & $75.75 \pm 2.11^{*}$ & 39.55 & $66.29 \pm 0.78^{*}$ & 53.77 \\
\hline$\beta$-Glucans & $90.34 \pm 0.71^{*}$ & 27.91 & $74.23 \pm 0.70$ & 48.23 \\
\hline A.aspera $400 \mathrm{mg} / \mathrm{kg}$ & $78.06 \pm 2.81 *$ & 37.71 & $68.71 \pm 0.68 *$ & 52.08 \\
\hline $\begin{array}{l}\text { A.aspera } 400 \mathrm{mg} / \mathrm{kg} \\
+\beta \text {-Glucans } 30 \\
\mathrm{mg} / \mathrm{kg}\end{array}$ & $72.24 \pm 0.67^{*}$ & 42.35 & $66.92 \pm 0.70^{*}$ & 53.33 \\
\hline
\end{tabular}

The results are shown as mean \pm S.E.M of six rats $(n=6) . * P<0.01$ is the statistical difference from control

\section{Burn wound healing:}

The A.aspera $+\beta$-Glucans and Silver Sulfadiazine $(1 \% \mathrm{w} / \mathrm{w})$ treated groups demonstrated a significant rise in percentage wound contraction in thermally induced burn wounds compared to the control group. On the 15th day of the research, the greatest percentage wound closure was seen, with $94.28 \pm 3.51$ and $89.18 \pm 3.65$ in the silver sulfadiazine $(1 \% \mathrm{w} / \mathrm{w})$ and A.aspera $+\beta$-Glucans treated groups, respectively. As a result, the wound closure percentage rose as the number of days increased (Table 6). 
TABLE 6: Effect of A.aspera and $\beta$-Glucans alone and in combination on thermal burn wound healing.

\begin{tabular}{|l|c|c|c|}
\hline & \multicolumn{3}{|c|}{ \% Wound Closure } \\
\hline Treatment Group & $\mathbf{5}^{\text {th }}$ Day & $\mathbf{1 0}^{\text {th }}$ Day & $\mathbf{1 5}^{\text {th }}$ Day \\
\hline Control & $2.11 \pm 0.23$ & $8.15 \pm 1.23$ & $19.18 \pm 1.43$ \\
\hline $\begin{array}{l}\text { Silver sulfadiazine } \\
(1 \% \text { w/w })\end{array}$ & $9.13 \pm 1.33$ & $58.15 \pm 3.26$ & $89.18 \pm 3.65^{*}$ \\
\hline$\beta$-Glucans & $5.26 \pm 1.42$ & $39.15 \pm 4.02$ & $67.24 \pm 3.55$ \\
\hline A.aspera & $7.16 \pm 1.24$ & $56.16 \pm 3.36$ & $88.16 \pm 3.46^{*}$ \\
\hline A.aspera $+\beta$-Glucans & $9.88 \pm 1.34$ & $61.23 \pm 3.25$ & $94.28 \pm 3.51^{*}$ \\
\hline
\end{tabular}

The results are shown as mean \pm S.E.M of six rats $(n=6) .{ }^{*} \mathrm{P}<0.01$ is the statistical difference from control

\section{Biochemical analysis:}

Table 7 shows the hexosamine and hydroxyproline and concentration of healed wound tissue. In diabetic wound control, hydroxyproline and hexosamine content were remarkably $(\mathrm{P}<0.01)$ lower than control. Compared to diabetic wound control, substantially $(\mathrm{P}<0.01)$ higher hydroxyproline and hexosamine concentrations were present in treatment groups.

When comparing diabetic wound management to standard wound control, there were a substantial rise in malondialdehyde (MDA) levels. Furthermore, when normal wound treatment was compared to diabetic control, GSH, SOD, and CAT levels were significantly lower (P $<0.01)$. Compared to diabetic wound control $(\mathrm{P}<0.01)$, treatment of A.aspera $+\beta$-Glucans for eight days significantly raised GSH, SOD, and CAT levels while MDA levels were found decreased (Table 7). 
TABLE 7: Biochemical study of wound tissue in diabetic rats caused by streptozotocin

\begin{tabular}{|c|c|c|c|c|c|c|}
\hline $\begin{array}{l}\text { Treatmen } \\
\text { t groups }\end{array}$ & $\begin{array}{l}\text { Hexosamine } \\
\text { content } \\
\text { (mg/100 mg } \\
\text { tissue) }\end{array}$ & $\begin{array}{l}\text { Hydroxyprol } \\
\text { ine content } \\
\text { (mg/g tissue) }\end{array}$ & $\begin{array}{c}\text { MDA } \\
(\mathbf{n m o l} / \mathbf{m} \\
\text { g of } \\
\text { protein) }\end{array}$ & $\begin{array}{c}\text { SOD } \\
(\mu \mathrm{g} / \mathrm{mg} \\
\text { of } \\
\text { protein })\end{array}$ & $\begin{array}{c}\text { Catalase } \\
(\mu \mathrm{g} / \mathrm{mg} \\
\text { of } \\
\text { protien })\end{array}$ & $\begin{array}{c}\text { GSH } \\
\text { (ng /mg of } \\
\text { protien) }\end{array}$ \\
\hline $\begin{array}{l}\text { Normal } \\
\text { control }\end{array}$ & $\begin{array}{c}0.731 \pm \\
0.041\end{array}$ & $13 \cdot 06 \pm 0 \cdot 76$ & $\begin{array}{c}4.07 \pm \\
0.47\end{array}$ & $\begin{array}{c}73.59 \pm \\
2.46\end{array}$ & $\begin{array}{c}39.85 \pm \\
3.09\end{array}$ & $18 \cdot 24 \pm 2 \cdot 22$ \\
\hline $\begin{array}{l}\text { Diabetic } \\
\text { control }\end{array}$ & $\begin{array}{l}0.193 \pm \\
0.020 *\end{array}$ & $3 \cdot 02 \pm 0 \cdot 39 *$ & $\begin{array}{c}13 \cdot 14 \pm \\
1 \cdot 01 * \\
\end{array}$ & $\begin{array}{c}38 \cdot 07 \pm \\
3.55^{*}\end{array}$ & $\begin{array}{c}11 \cdot 55 \pm \\
1.57 * \\
\end{array}$ & $7 \cdot 52 \pm 0 \cdot 81^{*}$ \\
\hline $\begin{array}{l}\text { Silver } \\
\text { sulfadiazin } \\
\text { e } \\
(1 \% \mathrm{w} / \mathrm{w}) \\
\end{array}$ & $\begin{array}{l}0.386 \pm \\
0.037 *\end{array}$ & $\begin{array}{c}10 \cdot 18 \pm \\
0.63 *\end{array}$ & $\begin{array}{c}12 \cdot 13 \pm \\
1.49 *\end{array}$ & $\begin{array}{c}30 \cdot 43 \pm \\
1.87 *\end{array}$ & $\begin{array}{c}12 \cdot 05 \pm \\
1 \cdot 58 *\end{array}$ & $8.03 \pm 0.73 *$ \\
\hline A.aspera & $\begin{array}{l}0.435 \pm \\
0.024^{*}\end{array}$ & $\begin{array}{c}10 \cdot 70 \pm \\
0 \cdot 52^{*}\end{array}$ & $\begin{array}{l}8 \cdot 53 \pm \\
1.49 *\end{array}$ & $\begin{array}{c}55 \cdot 21 \pm \\
5 \cdot 17^{*}\end{array}$ & $\begin{array}{c}30.92 \pm \\
3.99 *\end{array}$ & $15 \cdot 09 \pm 1.42^{*}$ \\
\hline$\beta$-Glucans & $\begin{array}{l}0.286 \pm \\
0.037 *\end{array}$ & $\begin{array}{c}18.18 \pm \\
0.63^{*}\end{array}$ & $\begin{array}{c}10 \cdot 13 \pm \\
1 \cdot 49 *\end{array}$ & $\begin{array}{c}36.73 \pm \\
2.09 *\end{array}$ & $\begin{array}{c}20 \cdot 92 \pm \\
3 \cdot 99 *\end{array}$ & $12.09 \pm 1.42 *$ \\
\hline $\begin{array}{l}\text { A.aspera + } \\
\beta \text {-Glucans }\end{array}$ & $\begin{array}{l}0.631 \pm \\
0.041 *\end{array}$ & $\begin{array}{c}12 \cdot 06 \pm \\
0.76 *\end{array}$ & $\begin{array}{l}6 \cdot 13 \pm \\
1 \cdot 49 *\end{array}$ & $\begin{array}{c}72 \cdot 82 \pm \\
2.03 *\end{array}$ & $\begin{array}{c}33.92 \pm \\
3.99 *\end{array}$ & $19.95 \pm 1.41 *$ \\
\hline
\end{tabular}

The results are shown as mean \pm S.E.M of six rats $(n=6) .{ }^{*} \mathrm{P}<0.01$ is the statistical difference from control

The IL-10 level was considerably $(\mathrm{P}<0.01)$ lower after wounding in the $2 \%$ Tween 80 treated $\operatorname{arm}\left(1^{\text {st }}\right.$ Day: $435.7 \pm 24.4 \mathrm{pg} / \mathrm{ml} ; 8^{\text {th }}$ day: $\left.536.9 \pm 28.4 \mathrm{pg} / \mathrm{ml}\right)$ than in the Indomethacin treated arm ( $1^{\text {st }}$ Day: $815.5 \pm 29.7 \mathrm{pg} / \mathrm{ml} ; 8^{\text {th }}$ day: $\left.1238.7 \pm 39.2 \mathrm{pg} / \mathrm{ml}\right)$. On days 1 and 8 following wounding, the IL-10 level in the A.aspera $+\beta$-Glucans treated group was significantly increased, reaching $850.0 \pm 28.2 \mathrm{pg} / \mathrm{ml}$ and $1389.6 \pm 49.6 \mathrm{pg} / \mathrm{ml}$, respectively. On the first and eighth days after being wounded, IL-10 levels increased to $817.0 \pm 28.3 \mathrm{pg} / \mathrm{ml}$ and $1240.6 \pm$ $49.7 \mathrm{pg} / \mathrm{ml}$ in the $\beta$-Glucans alone treated group, compared to $770.0 \pm 28.3 \mathrm{pg} / \mathrm{ml}$ and 1150.6 $\pm 49.7 \mathrm{pg} / \mathrm{ml}$ in the A.aspera alone treated group.

The IL-6 level in A.aspera $+\beta$-Glucans treated rats $(85.3 \pm 10.5 \mathrm{pg} / \mathrm{ml})$ was slightly less than that in the $2 \%$ Tween 80 treated group $(108.3 \pm 15.2 \mathrm{pg} / \mathrm{ml})$, at $24 \mathrm{~h}$ after wounding. At the same time, the IL-6 levels were greatly reduced $(\mathrm{P}<0.01)$ to $81.4 \pm 17.4 \mathrm{pg} / \mathrm{ml}$ in the A.aspera 
$+\beta$-Glucans treated group on day nine after wounding. On the other hand, on day nine following wounding, $2 \%$ Tween 80 treated rats had a high IL-6 level $(95.4 \pm 14.9$ pg/ml $)$

The level of IL-6 in the Indomethacin treated group $(68.0 \pm 15.8 \mathrm{pg} / \mathrm{ml})$ on $1^{\text {st }}$ day after wounding was sustantially $(\mathrm{P}<0.01)$ less in the $2 \%$ Tween 80 treated group, and the drop in IL6 levels was maintained $(42.7 \pm 12.6 \mathrm{pg} / \mathrm{ml}) 9^{\text {th }}$ day after wounding.

\section{Histopathologic study:}

When comparing the reference standard Silver sulfadiazine $(1 \% \mathrm{w} / \mathrm{w})$ and $\beta$-Glucans + A.aspera treated groups to the control group, excision biopsy of healed excision skin demonstrated virtually repaired skin architecture in both groups, with normal epithelization, fibrosis within the dermis and restitution of the adnexa (Figure 1).

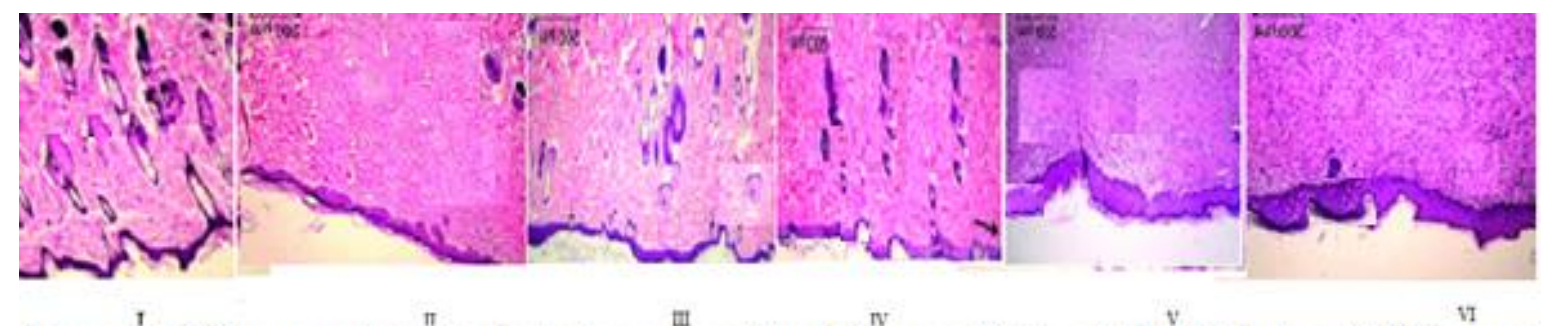

Figure 1: Histomorphological studies of excision biopsy of skin at the 15 th day (A) Group I: (control-treated with simple ointment) showing with less collagen and more macrophages with evidence of chronic inflammation. (B) Group II: (Diabetic control-treated with simple vintment) showing with less collagen and more macrophages with evidence of chronic inflammation(C) Group III: (standard-treated with $1 \%$ silver sulphadiazine) Granulation tissue formation, lesser fibroblasts and capillaries, and re-epithelialization, with reduced pus cells. (D) Group IV: (treated with CF of A.aspera) Granulation tissue formation, showing significan1 collagenation, fibroblasts and capillaries, and re-epithelialization (L) Group V: (treated with CF of $\beta$-Glucans) ) Granulation tissue formation, lesser fibroblasts and capillaries, and reepithelialization, with reduced pus cells(F) Group VI: (treated with $\beta$-Glucans + A.aspera) showing appreciable angiogenesis and granulation tissue formation with evidence of hai1 follicle and tissue restitution. Complete scaring resulted from incrcased collagenation and reepithelialisation. 


\section{Discussion:}

Acute toxicity is a preliminary study for the determination of drug safety. It is usually done to provide preliminary information on a substance mode of toxic action to determine dosage for a novel chemical and help with animal dose determination. A.aspera treatment did not cause any abnormalities in animals in our acute and sub-acute dermal toxicity studies.

Wound healing is a complicated biological process that may be divided into four phases: haemostasis period (0-several hours after damage), inflammation period (1-3 days), proliferation period (4-21 days), and remodelling period (21 days-1 year). ${ }^{1,34}$ Any of these disrupted phases results in poor healing, such as persistent hard-to-heal ulcers or severe scarring, which is a substantial and growing health and financial impact on our society. ${ }^{35,36}$ Current wound healing treatments focus on improving controllable healing variables such as infection clearance, nutritional support and mechanical protection. Novel therapeutic targets must be discovered, as well as more effective therapies must be developed. ${ }^{1,34}$

The shift from the inflammatory to the regenerative stages of wound healing is crucial in the healing process, and evidence is mounting that a defective transition is linked to wound healing issues. Thus, therapeutic development could be justified by focusing on elements that influence this phase shift. ${ }^{33}$ The inflammatory phase is required for haemostasis and the activation of the innate immune system, which defends us against infections and assists in the clearance of dead tissues. ${ }^{37}$ On the other hand, prolonged inflammation may compromise keratinocyte differentiation and stimulation, prohibiting wound healing from progressing through the normal stages. ${ }^{38}$ In addition, significant inflammation has been linked to a lot of scarring. ${ }^{39}$ During the process of healing, macrophages change from a pro-inflammatory M1 to a tissue repair M2 phenotype, generating anti-inflammatory mediators like IL-10, decoy IL-1 receptor type II, and IL-1R antagonist, as well as bioactive molecules like VEGF, IGF1 and TGF, which foster ECM synthesis, fibroblast proliferation, and angiogenesis. ${ }^{40,41}$ The transition from M1 to $\mathrm{M} 2$ is crucial for resolving inflammation and shifting the balance toward tissue healing. ${ }^{42}$ Sustained production of IL-1 $\beta$ in both mouse and human wounds inhibited upregulation of proliferator-activated receptor (PPAR) $\gamma$ action, which is required for the transition in macrophage phenotype in diabetes. Diabetes causes a deficient M1-M2 transition, which causes wound recovery to be delayed. ${ }^{43}$ The inflammation phase involves activating the immune system and the release of inflammatory mediators, regardless of the kind of wound. Thus, regulation of the aforementioned pathways is required for optimal wound healing. 
The findings of this investigation of A. aspera $+\beta$-Glucans wound healing activity on diabetic wounds revealed a considerably greater frequency of wound wound closure $(\mathrm{P}<0.01)$ in most post-wound days and a significantly shorter duration of epithelialization $(\mathrm{P}<0.01)$. This could be due to the immunomodulating activity of $\beta$ glucan $^{44}$ (responsible for fighting infections at the wound site and enhancing the migration and proliferation of keratinocytes and fibroblasts) and the added anti-inflammatory, anti-oxidant, and anti-bacterial effect of secondary metabolites (Table 1) of A. aspera. ${ }^{12,45-46}$ Furthermore, histological sections of the A. aspera + $\beta$-Glucans treated groups revealed significant fibroblast growth, increased cellular proliferation, and infiltration, indicating improved wound healing (Fig-1).

During the healing process, an infection caused primarily by anaerobic bacteria and S.aureus might prolong the inflammatory wound phase, resulting in wound failure. ${ }^{47}$ An in-vitro research of A. aspera root and shoot extracts in chloroform and methanol demonstrated substantial action against Klebsiella species, which could back up the current study's findings. ${ }^{48}$ Tannins detected in A. aspera chloroform extract were also found to suppress bacterial growth. ${ }^{49}$ The bacterial cell membrane was disrupted by triterpenoid saponins. ${ }^{50}$ Flavonoids astringent and antibacterial properties could help facilitate wound healing. Flavonoids, genistein, rutin, and chlorogenic acid, all contained in A. aspera, have an antibacterial impact that may aid wound healing, according to Ndhlala et al. ${ }^{51}$ Furthermore, $\beta$-Glucans are a wellknown macrophage stimulant that increases macrophage cytotoxicity and phagocytic capability. When wound macrophages are reduced, wound healing is delayed, according to Leibovich and Ross. ${ }^{52}$ As a result, it cannot be ruled out that modifying the macrophage activity of $\beta$-glucan promotes cutaneous wound healing. ${ }^{53}$ Furthermore, $\beta$-glucans have anti-infective activities and have antibacterial potential against many Gram-negative and Gram-positive bacteria. ${ }^{54}$ Higher wound contraction and a shorter duration of epithelialization were found in groups administered with A. aspera $+\beta$-Glucans alone and in combination when tried to compare to SO (simple ointment) control animals. A lengthy period of epithelium remodeling and wound closure was observed in the group treated with SO. However, wounds treated with A. aspera and $\beta$-Glucans alone or in combination were clean and healthy. The bacterial contamination and their metabolites in the SO-administered group might explain this, as bacteria and their metabolites inhibit wound contraction and impede wound healing.

Collagen synthesis, angiogenesis, maturation, and fibre stabilization may all contribute to improved tensile strength. ${ }^{55}$ As a result, the combination of A. aspera and $\beta$-Glucans could play a function in the synthesis of collagen, its maturation, and stabilization. Collagen is a 
component in developing cells in healing tissue that may be measured by looking at the hydroxyproline level. Elevated hydroxyproline levels in incision wounds indicate quicker collagen turnover, which results in faster healing and increases braking power of the treated wounds, indicating collagen fibre stability. ${ }^{56}$ Diabetic control rats had a significant drop in hydroxyproline concentration, as diabetic wounds have little or no granulation tissue. Hexosamine is a ground substance component required for the development of the extracellular matrix and, as a result, wound healing. To track the wound healing process, we measured the amount of hexosamine in the granulation tissues of excision wounds. Both in orally and topically administered groups, A.aspera $+\beta$-Glucans significantly increased hexosamine levels as compared to untreated control rats, indicating increased extracellular matrix synthesis and, as a result, adequate wound healing. Secondary metabolites of A. aspera may have aided the actions above either separately or due to their combined impact. ${ }^{57}$ The astringent and antioxidant qualities of Tannins aid wound healing by promoting tissue organization and regeneration. ${ }^{57}$ Flavonoids are astringent and antimicrobial, and they reduce lipid peroxidation by preventing or slowing cell necrosis and enhancing vascularity. ${ }^{58}$

$\beta$-Glucans also have a role in collagen fibres by activating immune and non-immune cells. Several receptors, Toll-like receptors (TLR-2, 4, 6) and complement receptor 3 (CR3), including the Dectin-1 receptor, scavenger receptor, and lactosylceramide, are involved in the $\beta$-glucan action mechanism of in the organism. ${ }^{59}$ The Dectin- 1 receptor is the most important since it is found in a wide range of immunocompetent cells, including neutrophils, DC, eosinophils, monocytes, T lymphocytes, macrophages, and cutaneous cells (fibroblasts and keratinocytes). $\beta$-glucan activates macrophages after attaching to the Dectin-1 receptor. Activated macrophages then secrete growth factors and cytokines that promote antiinflammatory and antibacterial actions, as well as dermal fibroblast migration to the lesion. These fibroblasts then proliferate in the wound, producing extracellular matrix (ECM) components like collagen to begin the remodelling process. ${ }^{5,60}$ As a result, the antimicrobial and antioxidant properties of phytochemicals found in A. aspera, as well as the effect of $\beta$-Glucans ${ }^{54}$ on tissue regeneration, collagen deposition, re-epithelialization, and angiogenesis (as demonstrated by histopathology study, Fig-1) not only accelerated wound healing but also increased tensile strength.

The findings of the dead space wound indicated that the combined therapy group had more granulation tissue weight and exudation than the control group, demonstrating A.aspera + $\beta$-Glucans potential to cure dead space wounds. Oxidative stress is caused by an excess of 
reactive oxygen species (ROS), which delays wound healing. As a result, reducing ROS may be a practical approach in repairing chronic wounds, and measuring antioxidants like catalase (CAT), superoxide dismutase (SOD), and other antioxidants in repaired excision wound tissue is critical. They assist in eliminating free radicals and expediting wound healing. ${ }^{61-62}$ In our study, A.aspera $+\beta$-Glucans showed remarkable in-vivo antioxidant activity by significantly $(\mathrm{P}<0.01)$ increasing the levels of antioxidant enzymes SOD and CAT, suggesting that A.aspera $+\beta$-Glucans could assist in avoiding oxidative damage and improving the healing process.

Because SOD catalyzes O2-dismutation and produces $\mathrm{H} 2 \mathrm{O} 2$, whilst CAT or peroxidases remove it, it appears logical to assume that ROS activity is coordinated. SOD-1 catalyzes the dismutation of potentially dangerous superoxide radicals into dioxygen and hydrogen peroxide. The extract-treated group had a considerable increase in CAT activity suggests that CAT might appropriately neutralize $\mathrm{H} 2 \mathrm{O} 2$ accumulated due to increased SOD activity. Reduced glutathione (GSH) is a significant endogenous thiol antioxidant in biological systems, serving as a cofactor for GPx to remove lipid hydroperoxide. ${ }^{63}$ Furthermore, endogenous antioxidants such as SOD, GSH, and CAT were decreased in diabetic rats, impacting wound repair and decreasing wound healing compared to diabetic control rats. Diabetes patients have higher levels of LPO and MDA, a secondary metabolite of LPO used as a biomarker to measure the extent of osmotic damage in an organism. It is formed when polyunsaturated lipids are degraded by reactive oxygen species (ROS). ${ }^{64}$ The injection of A.aspera + $\beta$-Glucans dramatically reduced serum MDA levels in this investigation. Flavonoids are also powerful antioxidants and free radical scavengers that protect cells from oxidative damage. ${ }^{65,66}$ Flavonoids hydroxylation and alkoxylation patterns are crucial factors in determining their antioxidant activity. ${ }^{67}$ According to recent research, saponin-rich n-BF extracted from the entire plant of A. aspera suppressed pro-inflammatory cells and reduced oxidative stress, perhaps owing to saponin's direct antioxidant effect mixed with an increase in the body's natural antioxidant enzyme-mediated defence system. ${ }^{68}$

Furthermore, $\beta$-glucan binding to TLRs activates macrophages and causes reactive oxygen species (ROS) to be released. After phagocytosis of intruding cells, the binding stimulates intracellular activities such as the respiratory burst (formation of free radicals and ROS such as superoxide radicals, hydrogen peroxide, NO, HOI [hypoiodous acid]), HOCl [hypochlorous acid. etc]. It causes an increase in the content and function of hydrolytic and metabolic enzymes, as well as signaling mechanisms that activate other phagocytes and cause the release of cytokines and other inflammatory mediators (e.g., IL-9, IL-1, tumour necrosis factor- 
$[\mathrm{TNF}]) .{ }^{69}$ As shown in this work and many others, ${ }^{12,} 68$ A.aspera's high anti-oxidant activity would have an added benefit when combined with $\beta$-glucan, as A.aspera serves to neutralize the ROS created by $\beta$-glucan binding to TLRs. At the same time, the natural anti-oxidant activity of $\beta$-glucans cannot be overlooked. $\beta$-glucan derived from baker's yeast has antioxidant effects (Saccharomyces cerevisiae) were tested using six different assays (DPPH inhibition activity, Chelating ability on ferrous ions, Ferric-reducing antioxidant power assay, ABTS assay, Inhibition of lipid peroxidation, Antioxidant activity against oxidative damage to DNA), and the property amplified significantly $(\mathrm{P} \leq 0.05)$ in a dose-response fashion.$^{70}$

The anti-inflammatory efficacy of A.aspera $+\beta$-Glucans was revealed in a rat model of paw edema induced by carrageenan. The anti-inflammatory impact of $A$. aspera $+\beta$-Glucans was significant in varied proportions of inhibition $(\mathrm{P}<0.01)$ at all periods. However, the most significant oedema inhibition percentage was reported 4 hours after induction $(\mathrm{P}<0.01)$. This is compatible with A. aspera's chloroform fraction having anti-inflammatory properties in vitro. ${ }^{71}$ The antiedematogenic efficacy was best in the latter phases of inflammation, comparable to the effect of nonsteroidal anti-inflammatory drugs like indomethacin, showing that the antiedematogenic activity is probably mediated by a cyclooxygenase enzyme inhibiting mechanism. ${ }^{72}$ The anti-inflammatory impact of A. aspera $+\beta$-Glucans could be linked to the actions of A. aspera secondary metabolites. Flavonoids and alkaloids showed antiinflammatory properties by disrupting the arachidonic acid metabolism pathway. ${ }^{73-75}$ These could cause A. aspera $+\beta$-Glucans highest percentage reduction of inflammation in the hind paw edema model induced by carrageenan.

A. aspera $+\beta$-Glucans demonstrated a statistically substantial reduction of both granuloma formation and exudate in the cotton pellet model. The sizable inhibitory effect of A. aspera + $\beta$-Glucans on exudate generation $(\mathrm{P}<0.01)$ (Table 6) reaffirm the findings of the carrageenaninduced edema model, indicating that both evidence supports the effectiveness of A. aspera + $\beta$-Glucans in lowering the exudative and proliferative components of inflammation. The combination's efficacy in reducing the proliferative period of inflammation, as evidenced by the greatest percentage of inhibition, is rationalized by the statistically significant suppression of granuloma formation $(53.33 \%)(\mathrm{P}<0.01)$.

IL-6 and TNF $\alpha$ induction was found as quickly as 12-24 hours after cutaneous injury, and these elements play a vital role in wound healing's inflammatory phase by promoting angiogenesis. ${ }^{76}$ IL-6 and TNF $\alpha$ levels were marginally lower in A.aspera $+\beta$-Glucans treated rats 24 hours 
after wounding, according to our findings. As a result, A.aspera $+\beta$-Glucans did not affect proinflammatory cytokines derived from macrophages during the early stages of recovery. Treatment with A.aspera $+\beta$-Glucans, on the other hand, raised IL-10 levels on days $1 \& 8$ after wounding. It's worth noting that IL-10 is a cytokine with anti-inflammatory properties produced by $\mathrm{T}$ lymphocytes and macrophages. ${ }^{77}$ The wound-healing environment appears to be influenced by IL-10, which lowers the expressiveness of profibrotic/proinflammatory mediators, resulting in less inflammatory cell recruitment to the wound. ${ }^{77}$ A.aspera $+\beta$ Glucans treatment boosted serum IL-10 levels while also lowering TNF and IL-6 expression, particularly on day eight following wounding. $\mathrm{TNF} \alpha$ has been reported to hinder collagen creation and hydroxyproline production, both required for wound healing's final proliferative phase. ${ }^{78}$ According to the findings, A.aspera $+\beta$-Glucans controls proinflammatory and antiinflammatory cytokines and the systemic immunological pathways linked to them, resulting in cellular proliferation.

Burn wounds are more difficult to cure because they generate a change in the skin by generating a lesion in the corneal layer, which is enough to cause the skin to lose its barrier function. ${ }^{79}$ Our findings revealed that the recorded erythema, thickness, and inflammation in control group animals, were nearly restored to normalcy in silver sulfadiazine and A.aspera $+\beta$-Glucans treated groups. As a result, A.aspera $+\beta-$-Glucans demonstrated intense wound healing activity in various animal models.

\section{Conclusion:}

The current study found that A.aspera $+\beta$-Glucans has promising and repeatable wound healing characteristics in diabetic wounds, as revealed by increased contraction of wounds and epithelization time in excision and thermal burn wound models. In the incision wounds, the breaking strength of wounds was raised in the A.aspera $+\beta$-Glucans treated groups, supported by higher hydroxyproline and antioxidant enzymes (SOD and CAT) in cotton pellet model. The anti-oxidant and anti-inflammatory activity of phytoconstituents contained in A.aspera and promotion of wound repair by immunological and non-immune mechanisms of $\beta$-Glucans may explain the wound-healing capabilities of A.aspera $+\beta$-Glucans. However, additional research is required to confirm the current findings. 


\section{Funding}

This research was funded by the Deanship of Scientific Research at King Khalid University; Grant number "RGP 2/186/42".

\section{Institutional Review Board Statement}

Not applicable.

\section{Informed Consent Statement}

Not applicable

\section{Data Availability Statement}

The data presented in this study is available on request from the corresponding author.

\section{Declaration of Conflicting Interests}

The authors declare no conflict of interest.

\section{Author Contributions}

All authors have read and agreed to the published version of the manuscript.

\begin{tabular}{|l|l|}
\hline $\begin{array}{l}\text { Krishnaraju } \\
\text { Venkatesan }\end{array}$ & $\begin{array}{l}\text { Conceptualisation, Formal analysis, Investigation, Methodology, } \\
\text { Project administration, Resources, Software, Supervision, } \\
\text { Validation, Visualization, Writing - original draft, Writing - } \\
\text { review \& editing }\end{array}$ \\
\hline Fazil Ahmad & $\begin{array}{l}\text { Data curation, Formal analysis, Methodology, Project } \\
\text { administration, Resources, Validation, Writing - review \& editing }\end{array}$ \\
\hline J. Muthu Mohamed & $\begin{array}{l}\text { Conceptualisation, Methodology, Project administration, Writing - } \\
\text { original draft, Writing - review \& editing }\end{array}$ \\
\hline $\begin{array}{l}\text { Rasheed Ahemad } \\
\text { Shaik }\end{array}$ & $\begin{array}{l}\text { Conceptualisation, Data curation, Methodology, Project } \\
\text { administration, Writing - review \& editing }\end{array}$ \\
\hline $\begin{array}{l}\text { Kayamkani } \\
\text { Abedulla Khan }\end{array}$ & $\begin{array}{l}\text { Conceptualisation, Data curation, Methodology, Project } \\
\text { administration, Validation, Writing - original draft, Writing - } \\
\text { review \& editing }\end{array}$ \\
\hline
\end{tabular}




\begin{tabular}{|c|c|}
\hline $\begin{array}{l}\text { Khalid Mohamad } \\
\text { Morsy Ibraheem }\end{array}$ & $\begin{array}{l}\text { Conceptualisation, Formal analysis, Funding acquisition, } \\
\text { Methodology, Project administration, Resources, Software, } \\
\text { Supervision, Validation, Visualization, Writing - original draft, } \\
\text { Writing - review \& editing. }\end{array}$ \\
\hline $\begin{array}{lr}\text { Mohamed } & \text { EL- } \\
\text { dosoky } & \text { Mohamed } \\
\text { Salama } & \end{array}$ & $\begin{array}{l}\text { Data curation, Formal analysis, Methodology, Project } \\
\text { administration, Validation, Visualisation, Writing - review \& } \\
\text { editing. }\end{array}$ \\
\hline Sally Yussef Abed & $\begin{array}{l}\text { Formal analysis, Methodology, Project administration, Software, } \\
\text { Supervision, Validation, Visualization, Writing - original draft, } \\
\text { Writing - review \& editing. }\end{array}$ \\
\hline $\begin{array}{l}\text { Doaa Ahmed } \\
\text { Ebrahim Radwan }\end{array}$ & $\begin{array}{l}\text { Conceptualisation, Investigation, Methodology, Project } \\
\text { administration, Resources, Software, Supervision, Validation, } \\
\text { Visualization, Writing - review \& editing }\end{array}$ \\
\hline $\begin{array}{l}\text { Premalatha } \\
\text { Paulsamy }\end{array}$ & $\begin{array}{l}\text { Data curation, Formal analysis, Methodology, Project } \\
\text { administration, Validation, Writing - original draft, Writing - } \\
\text { review \& editing }\end{array}$ \\
\hline Ester Mary Pappiya & $\begin{array}{l}\text { Conceptualisation, investigation, Methodology, Project } \\
\text { administration, Supervision, Writing - review \& editing }\end{array}$ \\
\hline $\begin{array}{l}\text { Kumarappan } \\
\text { Chidambaram }\end{array}$ & $\begin{array}{l}\text { Conceptualisation, investigation, Methodology, Project } \\
\text { administration, Supervision, Writing - review \& editing }\end{array}$ \\
\hline Geetha Kandasamy & $\begin{array}{l}\text { Formal analysis, Methodology, Project administration, Resources, } \\
\text { Software, Validation, Writing - review \& editing }\end{array}$ \\
\hline Kumar Venkatesan & $\begin{array}{l}\text { Conceptualisation, Investigation, Data curation, Project } \\
\text { administration, Resources, Software, Supervision, Validation, } \\
\text { Visualization, Writing - review \& editing }\end{array}$ \\
\hline $\begin{array}{l}\text { Rajalakshimi } \\
\text { Vasudevan }\end{array}$ & $\begin{array}{l}\text { Formal analysis, Methodology, Project administration, Resources, } \\
\text { Software, Validation, Writing - review \& editing }\end{array}$ \\
\hline
\end{tabular}

\section{Acknowledgements}

The authors extend their sincere appreciation to the Deanship of Scientific Research at King Khalid University for funding this study through the Large Research Group Project under grant number "RGP 2/186/42". 


\section{Reference:}

1. Guo S, Dipietro LA. Factors affecting wound healing. J Dent Res. 2010;89(3):219-29.

2. Gosain A, DiPietro LA. Aging and wound healing. World J Surg 2004;28:321-326.

3. Tandara AA, Mustoe TA. Oxygen in wound healing-more than a nutrient. World J Surg.2004; 28:294-300.

4. Mathieu D, Linke J-C, Wattel F. Non-healing wounds. In: Handbook on hyperbaric medicine, Mathieu DE, editor. Netherlands: Springer, 2006;pp. 401-427.

5. Fusté NP, Guasch M, Guillen P, Anerillas C, Cemeli T, Pedraza N, Ferrezuelo F, Encinas M, Moralejo M, Garí E. Barley $\beta$-glucan accelerates wound healing by favoring migration versus proliferation of human dermal fibroblasts. Carbohydr Polym. 2019;;210:389-398.

6. Mengie T, Mequanente S, Nigussie D, Legesse B, Makonnen E. Investigation of Wound Healing and Anti-Inflammatory Activities of Solvent Fractions of 80\% Methanol Leaf Extract of Achyranthes aspera L. (Amaranthaceae) in Rats. J Inflamm Res. 2021;14:1775-1787

7. Ahmad, A., Anjum, F. M., Zahoor, T., Nawaz, H., \& Dilshad, S. M. R.. Beta glucan: A valuable functional ingredient in foods. Critical Reviews in Food Science and Nutrition.2012; 52(3), 201-212.

8. Lundahl, M. L. E., Scanlan, E. M., \& Lavelle, E. C. Therapeutic potential of carbohydrates as regulators of macrophage activation. Biochemical Pharmacology.2017;146, 23-41.

9. Jin, J. W., Tang, S. Q., Rong, M. Z., \& Zhang, M. Q. (2018). Synergistic effect of dual targeting vaccine adjuvant with aminated $\beta$-glucan and $\mathrm{CpG}$ oligodeoxynucleotides for both humoral and cellular immune responses. Acta Biomaterialia. 2018; 78, 211-223.

10. Cutting KF. The cost-effectiveness of a novel soluble beta-glucan gel. J Wound Care. 2017;26(5):228-234.

11. S. Edwin, E. Edwin Jarald, L. Deb, A. Jain, H. Kinger, K.R. Dutt \& A. Amal Raj. Wound Healing and Antioxidant Activity of Achyranthesaspera, Pharmaceutical Biology.2008; 46:12, 824-828. 
12. Mengie T, Mequanente S, Nigussie D, Legesse B, Makonnen E. Investigation of Wound Healing and Anti-Inflammatory Activities of Solvent Fractions of 80\% Methanol Leaf Extract of Achyranthes aspera L. (Amaranthaceae) in Rats. J Inflamm Res. 2021;14:1775-1787.

13. Sasidharan S, Chen Y, Saravanan D, et al. Extraction, Isolation And Characterization Of Bioactive Compounds From Plants Extracts Institute For Research In Molecular Medicine (INFORM), Universiti Sains Malaysia, Minden 11800. African J Tradit Complement Altern Med. 2011;8:1-10. 33.

14. Ayoola GA, Coker HAB, Adesegun SA, et al. Phytochemical Screening and Antioxidant Activities of Some Selected Medicinal Plants Used for Malaria Therapy in Southwestern Nigeria. Trop J Pharm Res. 2008;7:1019-1024.

15. I. Suntar, E.K. Akkol, F.S. Senol, H. Keles, I. Erdogan Orhana, Investigating wound healing, tyrosinase inhibitory and antioxidant activities of the ethanol extracts of salvia cryptantha and Salvia cyanescens using in vivo and in vitro experimental models, J. Ethnopharmacol.2011; 135:71-77.

16. Oecd guidelines for the testing of chemicals. 2008

17. OECD . Test no. 410: repeated dose dermal toxicity: 21/28-day study, OECD guidelines for the testing of chemicals, section 4. Paris: OECD Publishing; 1981.

18. Manimekalai Pichaivel, Krishnaraju Venkatesan, Kalpana Krishnaraju, Saravanan VS, Premalatha Paulsamy, Divya Kuppan. Effect of Buchanania Lanzan on wound healing potential in diabetic rats. World J Pharm Sci 2021; 9(8): 97-100

19. Thakur R, Jain N, Pathak R, Sandhu SS. Practices in Wound Healing Studies of Plants. Evidence-Based Complementary and Alternative Medicine: eCAM. $2011 ; 2011$.

20. Nagar HK, Srivastava AK, Srivastava R, Kurmi ML, Chandel HS, Ranawat MS. Pharmacological Investigation of the Wound Healing Activity of Cestrum nocturnum (L.). Ointment in Wistar Albino Rats J Pharm. 2016;2016:8

21. Wang J, Ruan J, Cai Y, Luo Q, Xu H, Wu Y. In vitro and in vivo evaluation of the wound healing properties of Siegesbeckia pubescens. J Ethnopharmacol. 2011;134(3):1033-1038. 
22. Ilango K, Chitra V. Wound Healing and Anti-oxidant Activities of the Fruit Pulp of Limonia Acidissima Linn (Rutaceae) in Rats. Trop J Pharm Res. 2010;9:223-230.

23. Fikru A, Makonnen E, Eguale T, Debella A, Abie G. Evaluation of in vivo wound healing activity of methanol extract of Achyranthes aspera L. J Ethnopharmacol. 2012;143(2):469-474.

24. Mulisa E, Asres K, Engidawork E. Evaluation of wound healing and antiinflammatory activity of the rhizomes of Rumex abyssinicus J. (Polygonaceae) in mice. BMC Complement Altern Med. 2015;15:341.

25. Moghaddam ZP, Zolfaghari MR, Ghaemi EA, Mazandarani M, Mansourian AR, Taheri SA. Negative Performance of Root Extract of Onosma dichroanthum Boiss. on the Burn Wound Healing in an Animal Model. Arch Clin Microbial. 2011;2(5):1-5.

26. Kokane D, More R, Kale M, Nehete M, Mehendale P, Gadgoli C. Evaluation of wound healing activity of root of Mimosa pudica. J Ethnopharmacol. 2009;124(2):311-5.

27. Suntar IP, Akkol EK, Yilmazer D, Baykal T, Kirmizibekmez H, Alper M. Investigations on the in vivo wound healing potential of Hypericum perforatum L. J Ethnopharmacol. 2010;127(2):468-77

28. . Mulisa E, Asres K, Engidawork E. Evaluation of wound healing and antiinflammatory activity of the rhizomes of Rumex abyssinicus J. (Polygonaceae) in mice. BMC Complement Altern Med. 2015;15:341.

29. Afsar K, Rajesh kumar J, Venu Gopal PR. Assessment of Anti-inflammatory activity of Artemisia vulgaris leaves by Cotton Pellet Granuloma method in wistar albino rats. J Pharm Res. 2014;1:547.

30. Aziz TA, Marouf BH, Ahmed ZA, Hussain SA. Anti-Inflammatory Activity of Silibinin in Animal Models of Chronic Inflammation. Am J Pharmacol Sci. 2014;2:711.

31. Ghaisas MM, Kshirsagar SB, Sahane RS. Evaluation of wound healing activity of ferulic acid in diabetic rats. Int Wound J. 2014;11(5):523-32. 
32. Chen WC, Liou SS, Tzeng TF, Lee SL, Liu IM. Wound repair and anti-inflammatory potential of Lonicera japonica in excision wound-induced rats. BMC Complement Altern Med. 2012;12:226.

33. Fikru A, Makonnen E, Eguale T, Debella A, Abie Mekonnen G. Evaluation of in vivo wound healing activity of methanol extract of Achyranthes aspera L. J Ethnopharmacol. 2012;143(2):469-74.

34. Landén NX, Li D, Ståhle M. Transition from inflammation to proliferation: a critical step during wound healing. Cell Mol Life Sci. 2016;73(20):3861-3885.

35. Mustoe TA, O'Shaughnessy K, Kloeters O. Chronic wound pathogenesis and current treatment strategies: a unifying hypothesis. Plast Reconstr Surg. 2006;117(7 Suppl):35S-41S.

36. Sen CK, Gordillo GM, Roy S, Kirsner R, Lambert L, Hunt TK, Gottrup F, Gurtner GC, Longaker MT. Human skin wounds: a major and snowballing threat to public health and the economy. Wound Repair Regen. 2009;17(6):763-771.

37. Reinke JM, Sorg H. Wound repair and regeneration. Eur Surg Res. 2012;49(1):35-43.

38. Mustoe TA, O'Shaughnessy K, Kloeters O. Chronic wound pathogenesis and current treatment strategies: a unifying hypothesis. Plast Reconstr Surg. 2006;117(7 Suppl):35S-41S.

39. Xue M, Jackson CJ. Extracellular matrix reorganization during wound healing and its impact on abnormal scarring. Adv Wound Care (New Rochelle) 2015;4(3):119-136.

40. Brancato SK, Albina JE. Wound macrophages as key regulators of repair: origin, phenotype, and function. Am J Pathol. 2011;178(1):19-25.

41. Stein M, Keshav S, Harris N, Gordon S. Interleukin 4 potently enhances murine macrophage mannose receptor activity: a marker of alternative immunologic macrophage activation. J Exp Med. 1992;176(1):287-292.

42. Mosser DM, Edwards JP. Exploring the full spectrum of macrophage activation. Nat Rev Immunol. 2008;8(12):958-969.

43. Mirza RE, Fang MM, Novak ML, Urao N, Sui A, Ennis WJ, Koh TJ. Macrophage PPARgamma and impaired wound healing in type 2 diabetes. $\mathrm{J}$

Pathol. 2015;236(4):433-444. 
44. Muthuramalingam K, Choi SI, Hyun C, Kim YM, Cho M. $\beta$-Glucan-Based Wet Dressing for Cutaneous Wound Healing. Adv Wound Care (New Rochelle). 2019;8(4):125-135.

45. Krishnaveni A, Thaakur SR. Pharmacognostical And Preliminary Phytochemical Studies Of Achyranthes. Anc Sci Life. 2006;XXVI (1-2):1-5.38.

46. Mekonnen A, Sidamo T, Asres K, Engidawork E. In vivo wound healing activity and phytochemical screening of the crude extract and various fractions of Kalanchoe petitiana A. Rich (Crassulaceae) leaves in mice. J Ethnopharmacol. 2013;145(2):638646.

47. Abo A, Olugbuyiro JAO, Famakinde SA. Anti-infective and wound healing properties of flabellaria paniculata. African J Biomed Res. 2004;7:85-87.

48. Kaur M, Thakur Y, Rana RC. Antimicrobial Properties of Achyranthes aspera. Anc Sci Life. 2005;24(4):168-173

49. Khan TJ, Abbas G, Ahmad B, et al. Antibacterial activity of vacuum liquid chromatography (vlc) isolated fractions of chloroform extracts of seeds of achyranthes aspera. J Chem Soc Pakistan. 2012;34 (3):589-592

50. Netala VR, Ghosh SB, Bobbu P, Anitha D, Tartte V. Triterpenoid saponins: a review on biosynthesis, Applications and mechanism of their action. Int J Pharm Pharm Sci. 2015;7 (1):24-28.

51. Ndhlala AR, Ghebrehiwot HM, Ncube B, et al. Antimicrobial, anthelmintic activities and characterisation of functional phenolic acids of Achyranthes aspera Linn.: a medicinal plant used for the treatment of wounds and ringworm in east Africa. Front Pharmacol. 2015;6 (NOV):1-8.

52. Leibovich SJ, Ross R. The role of the macrophage in wound repair. A study with hydrocortisone and antimacrophage antimacrophage serum. Am J Pathol 1975; 78: 71-100.

53. Yun, Sungho \& Ku, Sae-Kwang \& Kwon, Young Sam. (2015). Effect of $\beta$-glucan Originated from Aureobasidium on Dermal Wound Healing in Normal Nude Mouse Model. Journal of Chitin and Chitosan. 20. 273-279.

54. Majtan J, Jesenak M. $\beta$-Glucans: Multi-Functional Modulator of Wound Healing. Molecules. 2018;23(4):806.

55. Murti K, Kumar U. Enhancement of wound healing with roots of Ficus racemosa L. in albino rats. Asian Pac J Trop Biomed. 2012;2 (4):276-280. 
56. Roy P, Amdekar S, Kumar A, Singh R, Sharma P, Singh V. In vivo antioxidative property, antimicrobial and wound healing activity of flower extracts of Pyrostegia venusta (Ker Gawl) Miers. J Ethnopharmacol. 2012;140(1):186-92.

57. Talukder FZ, Khan KA, Uddin R, Jahan N, Alam A. In vitro free radical scavenging and anti-hyperglycemic activities of Achyranthes aspera extract in alloxan-induced diabetic mice. Drug Discov Therapeutics. 2012;6(6):298-305

58. Fikru A, Makonnen E, Eguale T, Debella A, Abie G. Evaluation of in vivo wound healing activity of methanol extract of Achyranthes aspera L. J Ethnopharmacol. 2012;143(2):469-474.

59. Bloebaum R.M., Grant J.A., Sur S. Immunomodulation: The future of allergy and asthma treatment. Curr. Opin. Allergy Clin. Immunol. 2004;4:63-67.

60. Sun L., Zhao Y. The biological role of dectin-1 in immune response. Int. Rev. Immunol. 2007;26:349-364.

61. Mikhal'chik EV, Anurov MV, Titkova SM, Miroshnikova EA, Lukasheva EV, Deeva IB. Activity of antioxidant enzymes in the skin during surgical wounds. Bull Exp Biol Med. 2006;142(6):667-9.

62. Weindl G, Schaller M, Schafer-Korting M, Korting HC. Hyaluronic acid in the treatment and prevention of skin diseases: molecular biological, pharmaceutical and clinical aspects. Skin Pharmacol Physiol. 2004;17(5):207-13

63. Barua CC, Talukdar A, Begum SA, Pathak DC, Sarma DK, Borah RS, Gupta A. In vivo wound-healing efficacy and antioxidant activity of Achyranthes aspera in experimental burns. Pharm Biol. 2012 Jul;50(7):892-9.

64. Rahimi R, Nikfar S, Larijani B, Abdollahi M. A review on the role of antioxidants in the management of diabetes and its complications. Biomed Pharmacother 2005;59:365-373.

65. Arun M, Satish S, Anima P. Evaluation of wound healing, antioxidant and antimicrobial efficacy of Jasminum auriculatum Vahl. Leaves Avicenna J Phytomedicine. 2016;6(3):295-304.

66. Raut BK. A study of antioxidant activity, mineral and total vitamin c contents of stem, leaves, and inflorescence spike of achyranthes aspera var. Porphyrostachya Int J Phytopharm. 2013;4 (4):241-244.

67. Sharma V, Chaudhary U, Singh R, Janmeda P. Evaluation of quantitative and antioxidant activity of Achyranthes aspera roots and inflorescences. Asian J Pharm. 2014;8(1):1-7. 
68. Kothavade PS, Bulani VD, Nagmoti DM, Deshpande PS, Gawali NB, Juvekar AR. Therapeutic Effect of Saponin Rich Fraction of Achyranthes aspera Linn. on Adjuvant-Induced Arthritis in Sprague-Dawley Rats. Aoutoimune Dis. 2015;2015:8.

69. M. Novak \& V. Vetvicka. $\beta$-Glucans, History, and the Present: Immunomodulatory Aspects and Mechanisms of Action, Journal of Immunotoxicology. 2008;5:1, 47-57.

70. Khan AA, Gani A, Masoodi FA, Amin F, Wani IA, Khanday FA, Gani A. Structural, thermal, functional, antioxidant $\&$ antimicrobial properties of $\beta$-d-glucan extracted from baker's yeast (Saccharomyces cereviseae)-Effect of $\gamma$-irradiation. Carbohydr Polym. 2016;140:442-50.

71. Khuda F, Iqbal Z, Khan A, Shah Y, Ahmad L. Evaluation of anti-inflammatory activity of selected medicinal plants of Khyber Pakhtunkhwa, Pakistan. Pak J Pharm Sci. 2014;27:365-368.

72. Burke A, Smyth E, FitzGerald GA. Analgesic - Antipyretic Agents, Pharmacotherapy of Goat. Goodman Gilman's Pharmacolo Basis Therapeutics. 2006:671-715

73. Sowemimo A, Onakoya M, Fageyinbo MS, Fadoju T. Studies on the antiinflammatory and anti-nociceptive properties of Blepharis maderaspatensis leaves. Brazilian J Pharmacogn. 2013;23 (5):830-835

74. Goyal BR, Mahajan SG, Goyal RK, Mehta AA, Pharmacy LMC. Beneficial Effect of Achyranthes apsera Linn. in Toluene-Di-Isocyanate Induced Occupational Asthma in Rats. Pharmacology. 2007;2:54.

75. Tahiliani P, Kar A. Achyranthes aspera elevates thyroid hormone levels and decreases hepatic lipid peroxidation in male rats. J Ethnopharmacol. 2000;71(3):527-532.

76. Daley JM, Brancato SK, Thomay AA, Reichner JS, Albina JE. The phenotype of murine wound macrophages. J Leukoc Biol. 2010;87:59-67.

77. Sato Y, Ohshima T, Kondo T. Regulatory role of endogenous interleukin-10 in cutaneous inflammatory response of murine wound healing. Biochem Biophys Res Commun. 1999;265:194-199.

78. Siqueira MF, Chehab L, Krothpali N, Behl Y, Yang J, Braasch C. Impaired wound healing in mouse models of diabetes is mediated by TNF- $\alpha$ dysregulation and associated with enhanced activation of forkhead box $\mathrm{O} 1$ (FOXO1) Diabetologia. 2010;53:378-388. 
79. Mondal S, Reddy HK, Vidya PR, Ghosh D, Raja S, Ganapaty S. Evaluations of healing potential of ethanol extract from Macrothelypteris torresiana (Gaudich) aerial parts. International journal of phytomedicine. 2015;7(3):316-23. 